\title{
山羊血球免疫家鬼血清二對スル 各種動物血球，凝集態度二就广
}

笠原小兒保健研究所

本 間 正 雄

\section{【内容 抄 錄】}

山羊血球免疫家鬼血清二對スル異種動物血球ノ凝集態度二就テ研究シ，就中各型人血球，牛血球，家 鬼血球，烏蛇血球，食用蛙血球八勍レモ凝集元性テ示サザルコトキ知悉セリ。

目次

粕言

第 1 章、研究方法站二研究手技
第 2 章 研究成績

總 括

\section{舶言}

最近人類同種血球疑集素二關スル研究盛ンニシテ之ニ關スル報告枚擧二遑ア ラズ, 余モ亦指 $\ni$ 斯, 領域二於ヶル研究二染メ目下研鑚中二屬ス，其八間偶々 山羊血球免疫家鬼血清二對スル異種動物血球ノ凝集態度ニ就テ知ラントシ，手 ニシ得タル各種動物ヨリ探取セル血球 $习$ 供試シ, 今ヤ大體/成績 7 得タル テ報告セントス。

\section{第 1 章 研究方法韹二研究手技}

余入先ゾ研究順序トシテ山羊血球免疫家鬼血清习製出セり，郎チ體重 $2.0 \mathrm{~kg}$

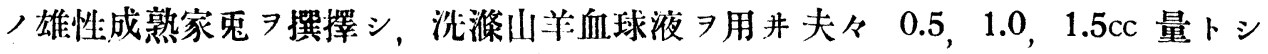

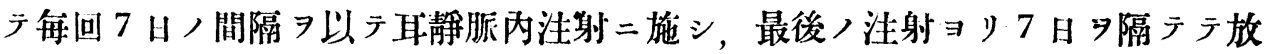
血シ, 析出血清 7 重湯煎上 $56^{\circ} \mathrm{C}=30$ 分間加温シ非能働性トナシ, 山羊血球二 對スル凝集效價 測定シ, 隇菌容器ニ入レラ揢封シ氷室內二貯藏セリ。而シテ

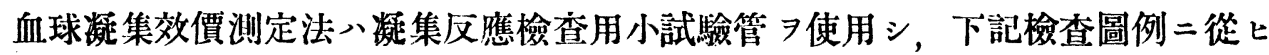
テ賽施セリ。 
血球凝集效價測定圖例

\begin{tabular}{|c|c|c|c|c|c|c|c|c|c|c|c|c|c|}
\hline $\begin{array}{l}\text { 試 驗 管 } \\
\text { 番 }\end{array}$ & 1 & 2 & 3 & 4 & 5 & 6 & 7 & 8 & 9 & 10 & 11 & 12 & 13 \\
\hline 生理的食盐水 & - & 0.5 & 0.5 & 0.5 & 0.9 & 0.5 & 0.5 & 0.5 & 0.9 & 0.5 & 0.5 & 0.5 & 0.5 \\
\hline $\begin{array}{l}5 \text { 倍稀䆁山羊血 } \\
\text { 球免发血清 }\end{array}$ & 0.5 & 0.5 & & & 0.1 & & & & $\begin{array}{l}\checkmark \exists y \\
0.1\end{array}$ & & & & 0 \\
\hline $0.35 \%$ 血球浮游液 & 0.5 & 0.5 & 0.5 & 0.5 & 0.4 & 0.5 & 0.5 & 0.5 & 0.5 & 0.5 & 0.5 & 0.5 & 0.5 \\
\hline （血清稀釋倍數） & $\left(10^{\prime}\right.$ & (20) & (40) & (80) & (100) & $(200)$ & $(400)$ & $(800)$ & $(1000)$ & $(2000)$ & $(4000)$ & $(8000)$ & (對照) \\
\hline
\end{tabular}

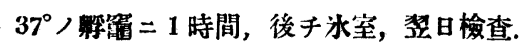

人以外，供試動物トシテハ牛，馬，豚，犬，猫，家鬼，もるるっ，らって， まうす，䳕，鳩，家鴨，鳥蛇，食用蛙ノ 14 種 $习$ 探擇シ，夫々探取血液二就テ温

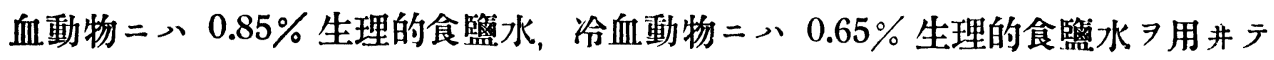
敦レモ遠心器二裝シ 3 回洗淮二附シ, 洗淮血球二就テ夫々前記食監水 7 泩加 原液量二復シ，之 7 血球原液トシテ毎回前記食監水 7 用井 $テ 0.35 \%$ 血球浮游 液 $\ni$ 製出使用ス, 少木檢查毎回山羊血球二對スル凝集效價 $尹$ 測定シ對照トナセ リ.

\section{第 2 章 研 究成 綪}

研究成績八總テ表示スルコトト七リ，因ミ二效價表示ニ就テハ凝集血球ガ試

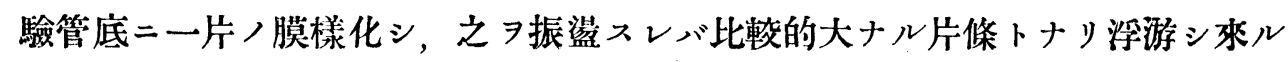

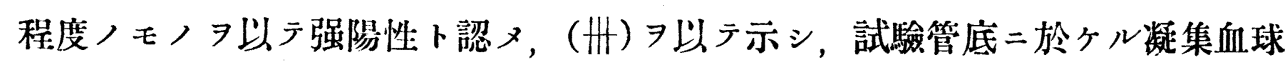
膜ガ前者二比シテ稍々溥ク, 振湆ニョリ生ズル細片ガ前者二比シテ細微ナルモ

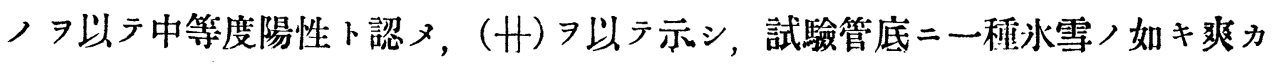

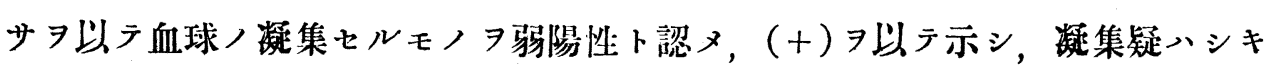

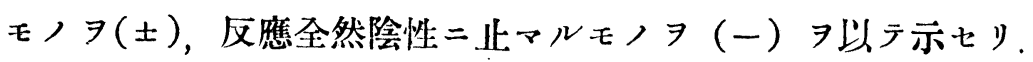


本間正雄进

(1129)

第 1 表 人血球 7 以テセル試羷 (昭和6年1月27日)

\begin{tabular}{|c|c|c|c|c|c|c|c|c|c|c|c|c|c|}
\hline $\begin{array}{l}\text { 血清稀釋倍數 } \\
\text { 血球種別 }\end{array}$ & 10 & 20 & 40 & 80 & 100 & 200 & 400 & 800 & 1000 & 2000 & 4000 & 8000 & K \\
\hline A 型人血球(本正) & \pm & - & - & - & - & - & - & - & - & - & - & - & - \\
\hline B 型 " & + & - & - & - & - & - & - & - & - & - & - & - & - \\
\hline A B型 " (大石) & - & - & - & - & - & - & - & - & - & - & - & - & - \\
\hline 0 型 " (本雪) & \pm & - & 一 & - & - & - & - & - & - & - & - & - & - \\
\hline 山羊血球 & W & W & 世 & 曲 & 曲 & H & $H$ & + & + & \pm & - & - & - \\
\hline
\end{tabular}

第 2 表 牛血球 9 以テセル試驗（昭和6年1月19日）

\begin{tabular}{|c|c|c|c|c|c|c|c|c|c|c|c|c|c|}
\hline $\begin{array}{l}\text { 血清稀䆁倍數 } \\
\text { 血球種別 }\end{array}$ & 10 & 20 & 40 & 80 & 100 & 200 & 400 & 800 & 1000 & 2000 & 4000 & 8000 & $\mathbf{K}$ \\
\hline 牛 血 球 & - & - & - & - & - & - & - & - & - & - & - & - & - \\
\hline 山羊血 球 & H & H & H & H & W & H & $H$ & + & + & \pm & - & - & - \\
\hline
\end{tabular}

第 3 表 馬血球 $\ni$ 以テセル試驗 （昭和6年1月13日）

\begin{tabular}{|c|c|c|c|c|c|c|c|c|c|c|c|c|c|}
\hline 血清稀釋倍數 & 10 & 20 & 40 & 80 & 100 & 200 & 400 & 800 & 1000 & 2000 & 4000 & 8000 & $\mathbf{K}$ \\
\hline 馬血 球 $(I)$ & \# & H & H & H & H & + & + & - & - & - & - & - & - \\
\hline 馬 血 球( (I) & 世 & 曲 & 世 & $H$ & + & \pm & - & - & - & - & - & - & 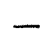 \\
\hline 山羊血球 & W & 曲 & W & W & W & H & + & + & + & \pm & - & - & - \\
\hline
\end{tabular}

第 4 表 豚血球 $\ni$ 以テセル試噞（昭和6年1月19日）

\begin{tabular}{ll|l|l|l|l|l|l|l|l|l|l|l|l|l}
\hline \hline 血清稀釋倍數 & 10 & 20 & 40 & 80 & 100 & 200 & 400 & 800 & 1000 & 2000 & 4000 & 8000 & $\mathrm{~K}$ \\
\hline 血球種别 & & &
\end{tabular}

第 5 表 犬血球 7 以テル試驗（昭和5年12月23日）

\begin{tabular}{|c|c|c|c|c|c|c|c|c|c|c|c|c|c|}
\hline 血清稀釋倍數種别 & 10 & 20 & 40 & 80 & 100 & 200 & 400 & 800 & 1000 & 2000 & 4000 & 8000 & $\mathrm{~K}$ \\
\hline 犬 血 球 & 曲 & W & $H$ & $H$ & + & + & - & - & - & - & - & - & - \\
\hline 山羊血 球 & m & W & W & W & $H$ & $H$ & + & + & + & \pm & - & - & - \\
\hline
\end{tabular}




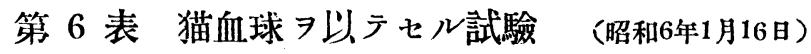

\begin{tabular}{l}
\hline 血清稀釋倍數 \\
\hline 種别
\end{tabular}

第 7 表 家鬼血球 7 以ヶル試驗（昭和5年12月23日）

\begin{tabular}{|c|c|c|c|c|c|c|c|c|c|c|c|c|c|}
\hline 血清稀釋倍數 & 10 & 20 & 40 & 80 & 100 & 200 & 400 & 800 & 1000 & 2000 & 4000 & 8000 & $\mathbf{K}$ \\
\hline 家 兔 血 球 & \pm & - & - & - & - & - & - & - & - & - & - & - & - \\
\hline 山羊 血 球 & H & \# & H & H & $H$ & H & + & + & + & \pm & - & - & - \\
\hline
\end{tabular}

第 8 表 るるっと血球

\begin{tabular}{|c|c|c|c|c|c|c|c|c|c|c|c|c|c|}
\hline $\begin{array}{l}\text { 血清稀釋倍數 } \\
\text { 血球種別 }\end{array}$ & 10 & 20 & 40 & 80 & 100 & 200 & 400 & 800 & 1000 & 2000 & 4000 & 8000 & $\mathbf{K}$ \\
\hline もるもっこ血球 & 曲 & \# & \# & + & \pm & - & - & - & - & - & - & - & - \\
\hline 山羊血 球 & \# & 世 & H & m & \# & H & + & + & + & \pm & - & - & - \\
\hline
\end{tabular}

·第 9 表 らって血球 7 以テセル試驗 （昭和6年1月20日）

\begin{tabular}{|c|c|c|c|c|c|c|c|c|c|c|c|c|c|}
\hline $\begin{array}{l}\text { 血清 稀釋倍數 } \\
\text { 血球種別 }\end{array}$ & 10 & 20 & 40 & 80 & 100 & 200 & 400 & 800 & 1000 & 2000 & 4000 & 8000 & $\mathrm{~K}$ \\
\hline$\zeta っ \tau$ 血球 & \# & H & W & + & + & \pm & - & - & - & - & -- & - & - \\
\hline 山羊 血 球 & 曲 & 曲 & W & H & \# & H & $H$ & + & + & \pm & - & - & - \\
\hline
\end{tabular}

第 10 表 まうす血球 $\ni$ 以テセル試驗（昭和6年1月20日）

\begin{tabular}{|c|c|c|c|c|c|c|c|c|c|c|c|c|c|}
\hline $\begin{array}{l}\text { 血清稀釋倍數 } \\
\text { 血球種別 }\end{array}$ & 10 & 20 & 40 & 80 & 100 & 200 & 400 & 800 & 1000 & 2000 & 4000 & 8000 & $\mathrm{~K}$ \\
\hline まう才血球 & \# & \# & 世 & H & $H$ & + & \pm & - & - & - & - & - & - \\
\hline 山羊 血 球 & W & 册 & 世 & \# & 曲 & W & $H$ & + & + & \pm & - & - & - \\
\hline
\end{tabular}


本間正䧹

第 11 表 ·鶟血球 7 以ヶル試驗（昭和6年1月9日）

\begin{tabular}{l|c|c|c|c|c|c|c|c|c|c|c|c|c|c}
\hline \hline 血清稀政倍數 & 10 & 20 & 40 & 80 & 100 & 200 & 400 & 800 & 1000 & 2000 & 4000 & 8000 & $\mathrm{~K}$. \\
\hline 血球種別
\end{tabular}

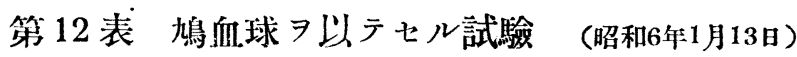

\begin{tabular}{|c|c|c|c|c|c|c|c|c|c|c|c|c|c|}
\hline 血清稀釋倍數 & 10 & 20 & 40 & 80 & 100 & 200 & 400 & 800 & 1000 & 2000 & 4000 & 8000 & \\
\hline 沜 血 球 & H & H & 世 & H & + & \pm & - & - & - & - & - & 一. & - \\
\hline 山羊 血 球 & 曲 & H & W & W & m & H & + & + & + & \pm & - & - & - \\
\hline
\end{tabular}

第 13 表 家鴨血球 7 以テル試驗 （昭和6年1月20日）

\begin{tabular}{c|c|c|c|c|c|c|c|c|c|c|c|c|c|c}
\hline \hline 血清稀䆁倍數 & 10 & 20 & 40 & 80 & 100 & 200 & 400 & 800 & 1000 & 2000 & 4000 & 8000 & $\mathrm{~K}$ \\
血球種別 & & &
\end{tabular}

第 14 表 鳥蛇血球 $\ni$ 以テセル試驗（昭和6年1月23日）

\begin{tabular}{|c|c|c|c|c|c|c|c|c|c|c|c|c|c|}
\hline 血清稀䆁倍數 & 10 & 20 & 40 & 80 & 100 & 200 & 400 & 800 & 1000 & 2000 & 4000 & 8000 & $\mathbf{K}$ \\
\hline 烏 蛇 血 球 & + & - & - & - & - & - & - & - & - & - & - & - & - \\
\hline 山羊 血 球 & W & $H$ & W & 曲 & \# & H & H & + & + & \pm & - & - & - \\
\hline
\end{tabular}

第 15 表 食用蛙血球 $\ni$ 以テセル試驗 （昭和6年1月23日）

\begin{tabular}{|c|c|c|c|c|c|c|c|c|c|c|c|c|c|}
\hline $\begin{array}{l}\text { 血清稀釋倍數 } \\
\text { 血球種別 }\end{array}$ & 10 & 20 & 40 & 80 & 100 & 200 & 400 & 800 & 1000 & 2000 & 4000 & 8000 & $\mathrm{~K}$ \\
\hline 食用蛙血球 & - & - & - & - & - & - & - & - & - & - & - & - & 一 \\
\hline 山羊 血 球 & 册 & 曲 & 冊 & H & H & $H$ & $H$ & + & + & \pm & - & - & - \\
\hline
\end{tabular}

郎チ上記ノ各成績 7 綜合シ表示スレバ第16表ノ如シ. 
第 16 表 山羊血球免疫家鬼血清二對スル各種動物血球ノ凝集態度

\begin{tabular}{|c|c|c|c|c|c|c|c|c|c|c|c|c|c|c|c|c|c|c|}
\hline 血球種別 & $\left|\begin{array}{l}人 \\
\text { 血 } \\
\text { 球型 }\end{array}\right|$ & $\begin{array}{l}\text { 人 } \mathrm{B} \\
\text { 血 } \\
\text { 球型 }\end{array}$ & $\mid \begin{array}{l}\text { 人 } \mathrm{A} \\
\text { 血 } \mathrm{B} \\
\text { 球型 }\end{array}$ & $\left|\begin{array}{l}\text { 人o } \\
\text { 血型 } \\
\text { 型 }\end{array}\right|$ & $\begin{array}{l}\text { 牛 } \\
\text { 血 } \\
\text { 球 }\end{array}$ & $\begin{array}{l}\text { 馬 } \\
\text { 血 } \\
\text { 球 }\end{array}$ & $\begin{array}{l}\text { 祭 } \\
\text { 血 } \\
\text { 球 }\end{array}$ & $\begin{array}{l}\text { 犬 } \\
\text { 血 } \\
\text { 球 }\end{array}$ & $\begin{array}{l}\text { 猫 } \\
\text { 血 } \\
\text { 球 }\end{array}$ & 家血 & $\begin{array}{ll}b \\
b \\
b \text { 血 } \\
0 \text { 球 }\end{array}$ & $\begin{array}{l}5 \\
\text { 血 } \\
\text { c球 }\end{array}$ & $\left|\begin{array}{l}\text { ま血 } \\
\vdots \\
\text { す球 }\end{array}\right|$ & $\begin{array}{l}\text { 鶹 } \\
\text { 血 } \\
\text { 球 }\end{array}$ & $\begin{array}{l}\text { 鳩 } \\
\text { 血 } \\
\text { 球 }\end{array}$ & 家血 & 舄血 & 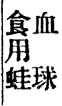 \\
\hline 凝集 & - & 10 & - & - & - & $\begin{array}{r}100- \\
400\end{array}$ & $10 \mathrm{C}$ & 200 & 200 & - & 80 & 100 & 200 & 20 & 100 & 400 & 10 & - \\
\hline
\end{tabular}

\section{總}

\section{括}

叙上余ノ實施セル山羊血球免疫家鬼血清ニ對スル各程動物血球ノ凝集態度二 關スル檢查成績ニョリ知リ得タル事項 ヨ列記スレバ下ノ如シ.

1. 人血球ハ山羊血球免疫家鬼血清二對シテ凝集七ズ，偶↔13型人血球ガ 10倍稀釋ニ於テ弱陽性 ヨ示セルモ之八特記スル價值ナシト思惟ス。

2. 哺乳動物血球二就テハ牛血球，家鬼血球，兩者就レモ山羊血球先疫家 鬼血清二對シテ凝策元性 ヨ示サズ，もるもっと血球ガ 80倍稀釋二於テ效價 7 示 ス以外，馬血球，豚血球，犬血球，猫血球，らって血球，まうす血球ハ就レモ 100倍乃至400倍稀釋汽凝集明暸ナリ。

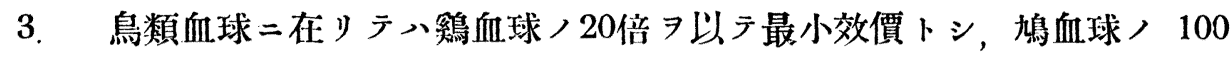
倍之二亞ギ，家鴨血球ノ凝集效價、400倍ノ高キヨ持セリ.

4. 爬蟲類二於テハ鳥蛇，食用蛙，兩者八血球八山羊血球货疫家鬼血清二 對シテ明暸ナル凝集元タリ得ザルコトラ示セり。

(昭和 6 年 1 月 28 日稿)

稿 $习$ 終ル二臨ミ恩即笠原博士㕸二笠原小兒保健研究所里見博士ノ終始御等篤 ナル御指導卜御校閱トヨ賜リタルコトヨ深謝ス。

\section{文献}

1) H. Sachs, Haemolytische Serumwirkung und Kcmplementbindung. Handbuch der Pathogenen Microorganismen, III. Auflage.

2) O. Thomson, Haemagglutination mit Einschlüss der Lehre von den Blutgruppen, elsenda. 3）鶴田善吾, 越山誠造, 血球凝集素二關スル研究，日本微生物學病理學雜誌，第 24 卷，第 11 號，炤和 5 年 10 月. 